\title{
Molecular characterizations of phosphoprotein of rabies virus circulating in Korea
}

\author{
Ha-Hyun Kim, Dong-Kun Yang*, Jeong Kuk Jeon, Soo-Dong Cho, Jae-Young Song \\ Animal, Plant and Fisheries Quarantine and Inspection Agency, Anyang 430-757, Korea \\ (Received: January 26, 2012; Revised: March 8, 2012; Accepted: March 14, 2012)
}

\begin{abstract}
Rabies is a major zoonotic disease that causes approximately 55,000 human deaths worldwide on an annual basis. The nucleocapsid protein and glycoprotein genes of the Korean rabies virus (RABV) have been subjected to molecular and phylogenetic analyses. Although the phosphoprotein (P) has several important functions in viral infection and pathogenicity, the genetic characterizations of the $\mathrm{P}$ of Korean RABV isolates have not yet been established. In the present study, we conducted genetic analyses of $\mathrm{P}$ genes of $24 \mathrm{RABV}$ isolates circulating in the Republic of Korea (hereafter, Korea) from 2008 to 2011. This study revealed that the P genes of Korean RABVs are genetically similar to those of RABV strains of lyssavirus genotype I including V739 (dogs, Korea), NNV-RAB-H (humans, India), NeiMeng925 (raccoon dogs, China), and RU9.RD (raccoon dogs, Russia). Among Korean isolates, the RABV P genes showed low variability in the variable domains among Korean isolates; they had specific consensus sequences and amino acid substitutions capable of identifying geographic characteristics and retained specific sequences thought to be important for viral function. These results provide important genetic characteristics and epidemiological information pertaining to the $\mathrm{P}$ gene of the Korean RABV.
\end{abstract}

Keywords : molecular epidemiology, $\mathrm{P}$ gene, rabies virus

\section{Introduction}

Rabies is a fatal viral disease in animals and humans that each year causes approximately 55,000 human deaths worldwide [22]. Rabies can be transmitted by various host species such as bats, red foxes, skunks, raccoon dogs, dogs, wolves, and mongooses according to geographic region [11]. Prior to 1993, dogs were considered the main vector for transmission of the rabies virus (RABV) to humans or other animals in the Korea. Since 1993, the raccoon dog has been the main vector between domestic and wild animals.

The first case of rabies was reported in 1907. Since then, many rabies cases were reported in Korea up to 1945 [7]. The occurrence of rabies decreased dramatically to an average of 32 cases per year by 1984, with no case of rabies reported between 1985 and 1992 due to effective implementation of the RABV control program using live and inactivated vaccines [10]. However, since rabies was identified in a dog in Gyeonggi-do Province in 1993, a few other rabies cases have been reported in Gyeonggi-do and Gangwon-do provinces each year [23]. Although a renewed national RABV control program that distributed bait vaccine was conducted in early 2000, rabies still occurs in some areas of Korea [23]. According to national data, no case was reported in Gyeonggi-do Province since 2007, whereas 18 rabies cases were reported in Gangwon-do Province (KAHIS program; Animal, Plant and Fisheries Quarantine and Inspection Agency, Korea).

The lyssavirus nucleocapsid protein $(\mathrm{N})$ genes were divided into seven genotypes (GTs) by phylogenetic analysis: 1, rabies virus (RABV); 2. Lagos bat virus (LBV); 3. Mokola virus (MOKV); 4. Duvenhage virus (DUVV); 5. European bat lyssavirus (EBLV) group 1; 6. European bat lyssavirus (EBLV) group 2; and 7 . Australian bat lyssavirus (ABLV) [1, 5].

The RABV contains approximately $12 \mathrm{~kb}$ of unsegmented negative-strand RNA for encoding the genes of the nucleocapsid protein $(\mathrm{N})$, phosphoprotein

\footnotetext{
*Corresponding author

Tel: +82-31-467-1783, Fax: +82-31-467-1797

E-mail: yangdk@korea.kr
} 
(P), matrix protein $(\mathrm{M})$, glycoprotein $(\mathrm{G})$, and the polymerase (L) [11]. The $\mathrm{N}$ protein is involved in encapsidation of the genomic RNA and the formation of an active cytoplasmic ribonucleoprotein complex essential for viral replication [25]. The nucleotide (nt) sequence of the $\mathrm{N}$ gene has been used as a molecular marker to explain geographic characteristics of RABV on regional and global levels [19]. The G protein is critically important for attachment of the virus to the cell, pathogenicity, immunogenicity, and neurovirulence $[11,24]$. The $\mathrm{G}$ gene has been used as another marker to study genetic diversity and antigenic typing because of having several major antigenic sites and relatedness with pathogenicity [24].

Along with the $\mathrm{G}$ protein, both the $\mathrm{P}$ and the $\mathrm{M}$ rabies proteins have been reported to be associated with the pathogenicity of RABV $[12,14]$. The P protein forms a ribonucleoprotein (RNP) that wraps around the viral RNA along with the $\mathrm{N}$ and $\mathrm{L}$ proteins. It plays an important role in transcription and replication in conjunction with the $\mathrm{L}$ protein $[11,12,14]$. Moreover, the $\mathrm{P}$ protein counteracts the host's interferon responses in infected cells $[2,3]$.

The genetic characterization of RABV is considered important for developing diagnostic and preventive measures, including a more effective vaccine. Most recently, the genetic characterizations of the $\mathrm{N}$ and $\mathrm{G}$ proteins of Korean RABV were analyzed in comparison with those of other reported RABVs [24]. The N and G genes of 11 Korean RABV isolates collected from animals diagnosed with rabies between 2008 and 2009 were subjected to molecular and phylogenetic analyses [24].

Although the $\mathrm{P}$ protein has been shown to have several important functions in viral infection and pathogenicity, the genetic characterization of the $\mathrm{P}$ gene of Korean RABV isolates had not been analyzed. In the present study, we analyzed the epidemiological and genetic characteristics of the $\mathrm{P}$ gene of $24 \mathrm{RABV}$ isolates circulating in Korea between 2008 and 2011.

\section{Materials and Methods}

\section{Samples}

Twenty-four isolates of RABV were obtained from brain samples collected from cattle, dogs, and raccoon dogs in Gangwon-do Province, Korea, from 2008 to 2011 (Table 1). These samples had previously been

Table 1. The $\mathrm{P}$ genes of Korean isolates detected and analyzed in this study

\begin{tabular}{|c|c|c|c|c|}
\hline Isolate & Species of origin & Region & Year of isolation & Accession Number \\
\hline KRVR0801 & Raccoon dog & Sokcho & 2008 & JN786934 \\
\hline KRVC0802 & Dog & Inje & 2008 & JN786930 \\
\hline KRVR0803 & Raccoon dog & Sokcho & 2008 & JN786935 \\
\hline KRVR0804 & Raccoon dog & Sokcho & 2008 & JN786936 \\
\hline KRVR0901 & Raccoon dog & Goseong & 2009 & JN786937 \\
\hline KRVB0902 & Cattle & Goseong & 2009 & JN786915 \\
\hline KRVB0903 & Cattle & Hongcheon & 2009 & JN786916 \\
\hline KRVB0904 & Cattle & Goseong & 2009 & JN786917 \\
\hline KRVB0905 & Cattle & Inje & 2009 & JN786918 \\
\hline KRVR0906 & Raccoon dog & Goseong & 2009 & JN786938 \\
\hline KRVB0907 & Cattle & Inje & 2009 & JN786919 \\
\hline KRVB0908 & Cattle & Goseong & 2009 & JN786920 \\
\hline KRVB0909 & Cattle & Goseong & 2009 & JN786921 \\
\hline KRVB0910 & Cattle & Goseong & 2009 & JN786922 \\
\hline KRVB1001 & Cattle & Goseong & 2010 & JN786923 \\
\hline KRVB1002 & Cattle & Goseong & 2010 & JN786924 \\
\hline KRVC1003 & Dog & Goseong & 2010 & JN786931 \\
\hline KRVB1004 & Cattle & Yangyang & 2010 & JN786925 \\
\hline KRVC1005 & Dog & Goseong & 2010 & JN786932 \\
\hline KRVB1006 & Cattle & Goseong & 2010 & JN786926 \\
\hline KRVC1007 & Dog & Goseong & 2010 & JN786933 \\
\hline KRVB1008 & Cattle & Goseong & 2010 & JN786927 \\
\hline KRVB1101 & Cattle & Goseong & 2011 & JN786928 \\
\hline KRVB1102 & Cattle & Inje & 2011 & JN786929 \\
\hline
\end{tabular}


diagnosed as rabies-positive by the indirect fluorescence antibody test (FAT) using a monoclonal antibody against the $\mathrm{N}$ protein of RABV (Median Diagnostics, Korea).

\section{RNA extraction and RT-PCR}

Total RNA was extracted from the lysates of 24 samples using the Qiagen RNeasy Mini Kit (Qiagen, USA) according to the manufacturer's instructions. RTPCRs were performed using a sequencing primer set for the P genes of 24 RABV isolates (Table 2). RT-PCR was conducted in a reaction mixture consisting of $10 \mu \mathrm{L}$ of denatured RNA, $1 \mu \mathrm{L}$ of each primer ( $50 \mathrm{pmol}), 10$ $\mu \mathrm{L}$ of $5 \times$ buffer $(12.5 \mathrm{mM} \mathrm{MgCl} 2), 2 \mu \mathrm{L}$ of dNTP mix, $2 \mu \mathrm{L}$ of enzyme mix (reverse transcriptase and Taq polymerase), and $24 \mu \mathrm{L}$ of distilled water (Qiagen, USA).

The cycling profile consisted of cDNA synthesis at $42^{\circ} \mathrm{C}$ for $30 \mathrm{~min}$, followed by 35 cycles at $95^{\circ} \mathrm{C}$ for 45 sec, $50^{\circ} \mathrm{C}$ for $45 \mathrm{sec}$, and $72^{\circ} \mathrm{C}$ for $1 \mathrm{~min}$, with a final extension at $72^{\circ} \mathrm{C}$ for $5 \mathrm{~min}$. The PCR products were visualized using electrophoresis on $1.8 \%$ agarose gel containing ethidium bromide.

\section{Cloning and DNA sequencing}

RT-PCR products were purified using a QIAEX II Gel Extraction kit (Qiagen, USA) and were ligated with the pGEM-T easy vector (Promega, USA) according to the manufacturers' instructions. Plasmid DNA was isolated from amplified Escherichia coli (DH5 $\alpha$ ), and recombinant plasmids were identified by EcoRI enzyme digestion (Bioneer, Korea). DNA sequencing of the purified plasmids was carried out using an ABI 3730xl automated DNA sequencer (Applied Biosystems, USA).

\section{Molecular characterization}

$P$ genes of the 24 Korean isolates were compared with those of the other RABV isolates (Table 3) submitted to NCBI using the DNAsis MAX DNA Basic module (MiraiBio, USA). Phylogenetic analyses were conducted using MEGA 4 [21]. Genetic distances were calculated using the Kimura 2-parameter correction at the nt level, and the phylogenetic tree was constructed using the neighbor-joining method with 1,000 bootstrap replicates. The nt and amino acid (aa) sequence similarities of $P$ genes of the 24 Korean isolates were performed using the homology and distance matrices method of DNAMAN program (ver. 6.0, Lynnon BioSoft; Canada).

\section{Results}

The nts of 24 Korean RABV isolates were sequenced and all data were deposited in GenBank under accession numbers JN786915-JN786938. The P genes of all 24 isolates showed 894 nts encoding 297 aas, which is quite common for RABV isolates. The similarities of $n t$ and aa sequences of the 24 Korean RABV P genes were found to be $98.9 \sim 100 \%$ and $98.6 \sim 100 \%$, respectively, scoring high similarities regardless of the species of origin (Table 4).

The $\mathrm{P}$ gene open reading frame sequences of 24 Korean RABV isolates were compared with those of previously reported RABV isolates. Among the reported RABV isolates, the $\mathrm{P}$ genes of the Korean RABVs showed the highest $\mathrm{nt}$ and aa similarities (98.4 99.0\% and $98.3 \sim 99.0 \%$, respectively) with Korean dog RABV isolate V739 (Table 4). In addition, Korean RABVs showed high (>95\%) nt and aa similarities with NNVRAB-H (humans, India), NeiMeng925 (raccoon dogs, China), and RU9.RD (raccoon dogs, Russia; Table 4).

Similar to previous reports [12], the phylogenetic tree of $\mathrm{P}$ gene nt sequences in this study showed two large genetic clusters (Chiroptera-related and Carnivora-related RABVs; Fig. 1). All 24 Korean RABVs were included in the Carnivora-related RABV cluster and were closely clustered with one another within the same lineage regardless of species origin. In addition, Korean isolates were most closely related with the V739 isolated from Korean dogs as well as being closely related to NeiMeng925 (raccoon dogs, China), RU9.RD (raccoon

Table 2. Oligonucleotide primers for amplifying the $\mathrm{P}$ genes of rabies viruses in this study

\begin{tabular}{clcc}
\hline \hline Primer name & \multicolumn{1}{c}{ Primer sequence (5'-3') } & Region $(\mathrm{nt})^{*}$ & Size $(\mathrm{bp})$ \\
\hline RVPF1 & GAGATCGCACATACGGAGAT & $1321 \sim 1340$ & 611 \\
RVPR1 & CTGGTCCCTGGAGGGAATCCT & $1932 \sim 1908$ & \\
RVPF2 & CAAATAGTCAGACAAATGA & $1820 \sim 1838$ & 833 \\
RVPR2 & AAGTTCCTCATGTTCTTCTTGC & $2653 \sim 2631$ & \\
\hline
\end{tabular}

${ }^{*}$ The position of primers are based on the PV strain (GenBank accession no. M13215). 
dogs, Russia), and NNV-RAB-H (humans, India). These findings are consistent with the similarities in nts. Finally, skunk (V211.SK and V216.SK) and raccoon dog (FL.RAC and NY.RAC) RABV isolates detected in the United States were included in the Chiroptera-related RABV cluster in this study, as previously reported [12] (Fig. 1).

Two conserved domains (CD1 and CD 2) and two variable domains (VD1 and VD2) have been identified based on aa sequence multiple alignments of RABV P gene (Fig. 2). Significant differences were not detected between the conserved and variable domains in the 24 Korean RABV P genes in this study (Fig. 2). However, specific consensus sequences of Korean RABVs lineage including V739, NeiMeng925, RU9.RD, and NNV-RAB$\mathrm{H}$ in the phylogenetic tree were detected as KEPS (N/

Table 3. Reference rabies virus isolates used in this study

\begin{tabular}{|c|c|c|c|c|c|c|c|}
\hline Isolate & $\begin{array}{l}\text { Species of } \\
\text { origin }\end{array}$ & Country & $\begin{array}{l}\text { Accession } \\
\text { Number }\end{array}$ & Isolate & $\begin{array}{c}\text { Species of } \\
\text { origin }\end{array}$ & Country & $\begin{array}{c}\text { Accession } \\
\text { Number }\end{array}$ \\
\hline Mokola & Unknown & Unknown & Y09762 & ONT1.RFX & Arctic fox & Canada & AF369265 \\
\hline $\mathrm{ABL}$ & Human & Australia & AF418014 & ONT5.RFX & Arctic fox & Canada & AF369269 \\
\hline ERA & Vaccine strain & Germany & EF206707 & ARC5.RFX & Arctic fox & Canada & AF369270 \\
\hline PV & Unknown & Unknown & M13215 & V280.FX & European fox & France & AF369278 \\
\hline NNV-RAB-H & Human & India & EF437215 & V660.FX & Middle east fox & Israel & AF369280 \\
\hline $\begin{array}{l}08022 \mathrm{MAR} / \\
2007\end{array}$ & Bovine & Morocco & GU798462 & V265.BFX & Bat-eared fox & Tanzania & AF369296 \\
\hline I15.DG & Dog & India & AF369309 & V213.SK & Coyote & U.S.A. & AF369289 \\
\hline I19.DG & Dog & India & AF369310 & FT2891.DG & Coyote & U.S.A. & AF369308 \\
\hline IR5.DG & Dog & Iran & AF369311 & V211.SK & Skunk & U.S.A. & AF369287 \\
\hline V027.DG & Dog & Tunisia & AF369322 & V216.SK & Skunk & U.S.A. & AF369291 \\
\hline V113.DG & Dog & Sri Lanka & AF369320 & KY2877.SK & Skunk & U.S.A. & AF369292 \\
\hline V121.DG & Dog & Nepal & AF369317 & V037.MG & Mongoose & Botswana & AF369300 \\
\hline V118.DG & Dog & Sri Lanka & AF369321 & V264.MG & Mongoose & South Africa & AF369302 \\
\hline V461.DG & Dog & Nigeria & AF369326 & 3694.MYO & Myotis sp. (bat) & Canada & AF369349 \\
\hline V464.DG & Dog & Nigeria & AF369328 & V089.LBB & Myotis lucifugus (bat) & Canada & AF369343 \\
\hline V739 & Dog & Korea & DQ275562 & 88BC1319BB & $\begin{array}{l}\text { Eptesicus fuscus } \\
\text { (big brown bat) }\end{array}$ & Canada & AF369341 \\
\hline M29.DG & Dog & Mexico & AF369313 & 89SK1461BB & $\begin{array}{l}\text { Eptesicus fuscus } \\
\text { (big brown bat) }\end{array}$ & Canada & AF369340 \\
\hline DRV-Mexico & Dog & Mexico & HQ450386 & 93ON0058BB & $\begin{array}{l}\text { Eptesicus fuscus } \\
\text { (big brown bat) }\end{array}$ & Canada & AF369338 \\
\hline ZAMRAV5100 & 0 Dog & Zambia & $\mathrm{AB} 285215$ & V230.BBB & $\begin{array}{l}\text { Eptesicus fuscus } \\
\text { (big brown bat) }\end{array}$ & U.S.A. & AF369342 \\
\hline $\begin{array}{l}08056 \mathrm{MAR} / \\
2005\end{array}$ & Dog & Morocco & GU798489 & M4.VB & Vampire bat & Canada & AF369366 \\
\hline $\begin{array}{l}08116 \mathrm{MAR} / \\
2006\end{array}$ & Dog & Morocco & GU798414 & P4.VB & Vampire bat & Canada & AF369364 \\
\hline $\begin{array}{l}\text { 09011Ceuta/ } \\
1991\end{array}$ & Dog & Spain & GU798429 & V077.SHB & $\begin{array}{l}\text { Lasionycteris noctiva- } \\
\text { gans (silver-haired bat) }\end{array}$ & Canada & AF369346 \\
\hline NeiMeng925 & Raccoon dog & China & FJ415313 & SHBRV-18 & $\begin{array}{l}\text { Lasionycteris noctiva- } \\
\text { gans (bat) }\end{array}$ & U.S.A. & AY705373 \\
\hline RU9.RD & Raccoon dog & Russia & AF369284 & V103.HB & $\begin{array}{l}\text { Lasiurus cinereus } \\
\text { (hoary bat) }\end{array}$ & Canada & AF369347 \\
\hline FL.RAC & Raccoon & U.S.A. & AF369294 & 6832.RB & $\begin{array}{l}\text { Lasiurus borealis } \\
\text { (red bat) }\end{array}$ & Canada & AF369351 \\
\hline NY.RAC & Raccoon & U.S.A. & AF369293 & V235.FTB & $\begin{array}{l}\text { Tadarida brasiliensis } \\
\text { (free-tailed bat) }\end{array}$ & U.S.A. & AF369359 \\
\hline
\end{tabular}


S) LGGVTTA encoded by aas 61 72 within the VD1 (Fig. 2). In addition, a specific substitution between VDI and VD2 was found in aa 91 of Korean RABV P genes (Fig. 2). This aa was substituted by $\mathrm{Val}_{91}$ in only Korean RABVs and was not found in other isolates such as PV $\left(\mathrm{Leu}_{91}\right)$ and V739 (Ile ${ }_{91}$ ) (Fig. 2).

Phosphoacceptors related to protein kinase $\mathrm{C}$ (PKC) or RABV protein kinase in the $\mathrm{P}$ protein of the CVS strain were reported as $\mathrm{Ser}_{63}, \mathrm{Ser}_{64}, \mathrm{Ser}_{162}, \mathrm{Ser}_{210}$, and $\operatorname{Ser}_{271}$ [6]. All but phosphoacceptor $\operatorname{Ser}_{63}$ were retained in all Korean RABVs. Instead, $\operatorname{Ser}_{63}$ was substituted with $\mathrm{Pro}_{63}$ in all Korean RABVs (Fig. 2). The four Nterminally truncated $\mathrm{P}$ proteins could be synthesized due to translational initiation at internal $\mathrm{Met}_{20}, \mathrm{Met}_{53}, \mathrm{Met}_{69}$, and Met $_{83}$ in the CVS strain [4, 14]. Of the four aforementioned methionine residues, Met $_{69}$ was substituted by $\mathrm{Val}_{69}$ in all Korean RABVs (Fig. 2).

The binding site for the cellular protein, cytoplasmic dynein light chain (LC8), was recently detected in $\mathrm{P}$ protein residues 139 151 (N'-RSSEDKSTQTTGR-C') of the PV strain of RABV and is thought to be involved in viral RNP axoplasmic transport along the microtubule network with the $\mathrm{D}_{143}$ and $\mathrm{Q}_{147}$ residues being critical in this interaction [9, 17, 18]. Also, the consensus sequence $(\mathrm{K} / \mathrm{R}) \mathrm{XTQT}$ has been reported to be the common target-acceptor of LC8 and is a conserved LC8 binding motif [13]. This consensus sequence was located within the VD2 region and strongly conserved in all Korean RABVs examined in this study (Fig. 2). Finally, the lysine-rich motif (N'-FSKKYKF-C'), an important component of C-terminal $\mathrm{N}$ protein-binding, was also conserved in aas 209 215 in all Korean RABVs (Fig. 2).

Table 4. The similarities (\%) of nucleotide (nt) and amino acid (aa) sequences

\begin{tabular}{|c|c|c|c|c|c|}
\hline \multirow{2}{*}{ Isolate } & \multicolumn{2}{|c|}{ P genes of 24 Korean RABVs ${ }^{*}$} & \multirow{2}{*}{ Isolate } & \multicolumn{2}{|c|}{ P genes of 24 Korean RABVs ${ }^{*}$} \\
\hline & nt similarities & aa similarities & & nt similarities & aa similarities \\
\hline Mokola & $55.6 \sim 55.9$ & $45.6 \sim 46.3$ & ONT1.RFX & $90.4 \sim 90.9$ & $92.2 \sim 92.9$ \\
\hline $\mathrm{ABL}$ & $69.0 \sim 69.4$ & $72.9 \sim 73.9$ & ONT5.RFX & $89.8 \sim 90.3$ & $92.9 \sim 93.6$ \\
\hline ERA & $85.2 \sim 85.9$ & $88.8 \sim 89.8$ & ARC5.RFX & $89.5 \sim 90.0$ & $92.9 \sim 93.6$ \\
\hline PV & $84.9 \sim 85.6$ & $88.2 \sim 89.2$ & V280.FX & $86.1 \sim 86.6$ & $90.5 \sim 91.6$ \\
\hline NNV-RAB-H & $96.5 \sim 97.0$ & $96.3 \sim 97.3$ & V660.FX & $86.1 \sim 86.6$ & $88.9 \sim 89.9$ \\
\hline 08022MAR/2007 & $86.9 \sim 87.4$ & $91.2 \sim 91.9$ & V265.BFX & $84.5 \sim 85.0$ & $89.5 \sim 90.5$ \\
\hline I15.DG & $83.0 \sim 83.4$ & $87.5 \sim 88.5$ & V213.SK & $85.5 \sim 85.9$ & $88.9 \sim 89.5$ \\
\hline I19.DG & $91.7 \sim 92.3$ & $93.9 \sim 94.6$ & FT2891.DG & $85.0 \sim 85.6$ & $89.2 \sim 89.8$ \\
\hline IR5.DG & $86.6 \sim 87.1$ & $90.2 \sim 91.2$ & V211.SK & $78.9 \sim 79.3$ & $84.1 \sim 84.8$ \\
\hline V027.DG & $86.3 \sim 86.9$ & $91.9 \sim 92.9$ & V216.SK & $78.9 \sim 79.3$ & $84.1 \sim 84.8$ \\
\hline V113.DG & $83.4 \sim 84.0$ & $89.5 \sim 90.2$ & KY2877.SK & $84.7 \sim 85.3$ & $89.8 \sim 90.8$ \\
\hline V121.DG & $91.5 \sim 91.9$ & $94.2 \sim 94.9$ & V037.MG & $83.8 \sim 84.3$ & $87.1 \sim 88.1$ \\
\hline V118.DG & $83.3 \sim 83.8$ & $89.2 \sim 89.8$ & V264.MG & $83.3 \sim 83.8$ & $85.5 \sim 86.5$ \\
\hline V461.DG & $83.3 \sim 83.9$ & $88.9 \sim 89.5$ & 3694.MYO & $82.4 \sim 83.0$ & $86.8 \sim 87.5$ \\
\hline V464.DG & $83.3 \sim 83.9$ & $88.9 \sim 89.5$ & V089.LBB & $81.9 \sim 82.5$ & $86.1 \sim 87.1$ \\
\hline V739 & $98.4 \sim 99.0$ & $98.3 \sim 99.0$ & 88BC1319BB & $79.4 \sim 79.9$ & $83.1 \sim 83.7$ \\
\hline M29.DG & $86.7 \sim 87.1$ & $89.5 \sim 90.2$ & 89SK1461BB & $80.6 \sim 81.3$ & $86.4 \sim 87.1$ \\
\hline DRV-Mexico & $86.8 \sim 87.2$ & $90.8 \sim 91.5$ & 93ON0058BB & $80.6 \sim 81.1$ & $85.8 \sim 86.4$ \\
\hline ZAMRAV5100 & $85.5 \sim 86.0$ & $90.2 \sim 91.2$ & V230.BBB & $79.4 \sim 79.9$ & $83.8 \sim 84.5$ \\
\hline 08056MAR/2005 & $86.2 \sim 86.8$ & $90.5 \sim 91.5$ & M4.VB & $78.6 \sim 79.5$ & $82.8 \sim 83.4$ \\
\hline 08116MAR/2006 & $86.3 \sim 86.9$ & $90.8 \sim 91.9$ & P4.VB & $78.1 \sim 78.7$ & $82.8 \sim 83.4$ \\
\hline 09011Ceuta/1991 & $86.9 \sim 87.4$ & $90.8 \sim 91.9$ & V077.SHB & $80.2 \sim 80.6$ & $83.7 \sim 84.7$ \\
\hline NeiMeng925 & $95.5 \sim 95.9$ & $95.9 \sim 97.0$ & SHBRV-18 & $79.7 \sim 80.0$ & $84.1 \sim 85.1$ \\
\hline RU9.RD & $96.5 \sim 97.0$ & $96.3 \sim 97.3$ & V103.HB & $78.5 \sim 78.9$ & $82.4 \sim 83.4$ \\
\hline FL.RAC & $78.5 \sim 78.9$ & $84.4 \sim 85.4$ & 6832.RB & $79.5 \sim 79.9$ & $83.1 \sim 84.1$ \\
\hline NY.RAC & $78.1 \sim 78.5$ & $83.1 \sim 84.1$ & V235.FTB & $78.6 \sim 79.2$ & $83.8 \sim 84.5$ \\
\hline
\end{tabular}

${ }^{*}$ The similarities (\%) of nt and aa sequences of 24 Korean RABV P genes were found to be $98.9 \sim 100 \%$ and $98.3 \sim 100 \%$, respectively. 


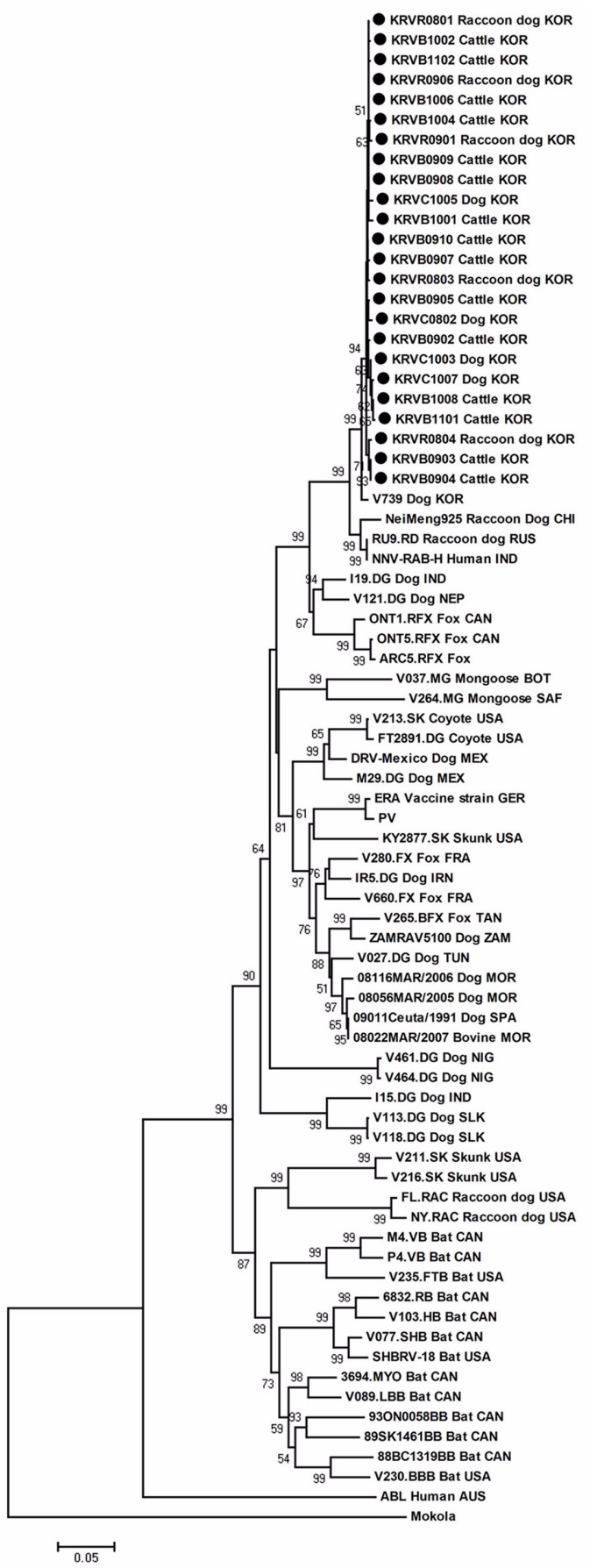

Fig. 1. Phylogenetic analysis based on the ORF nucleotide sequences of $P$ gene of 24 Korean rabies virus (RABV) isolates with other RABV isolates submitted to NCBI GenBank. Mokola virus used as an outgroup. Genetic distances were calculated using the Kimura-2 parameter model at the nucleotide level and the phylogenetic tree was constructed using the neighborjoining method with 1,000 bootstrap replicates using MEGA 4. Bootstrap values above 50 are shown. The abbreviations of countries are as follows: AUS, Australia; BOT, Botswana; CAN, Canada; CHI, China; FRA, France; GER, Germany; IND, India; IRN, Iran; ISR, Israel; KOR, Korea; MEX, Mexico; MOR, Morocco; NEP, Nepal; NIG, Nigeria; RUS, Russia; SAF, South Africa; SLK, Sri Lanka; SPA, Spain; TAN, Tanzania; TUN, Tunisia; USA, United States; ZAM, Zambia. 

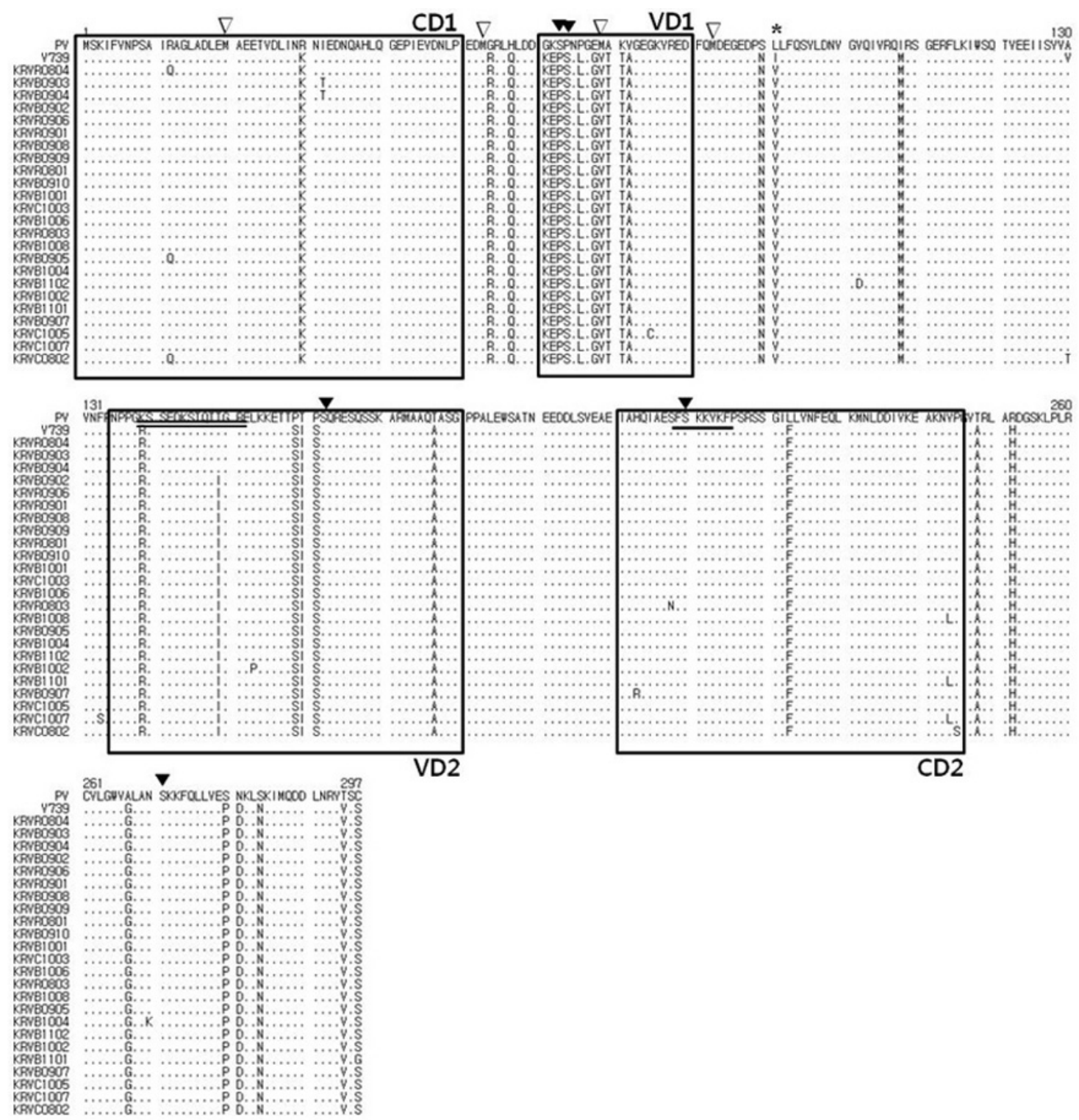

Fig. 2. Comparison of $\mathrm{P}$ protein amino acid sequences of 24 Korean RABVs with those of PV strain and V739 (Korean $\operatorname{dog}$ ) isolate. Only different amino acids from the PV sequence are indicated and dots indicate amino acids that are in agreement with the sequence of PV strain. Boxes with CD1 and CD2 indicate conserved domains, while boxes with VD1 and VD2 delimitate variable domains. Black triangles indicate the positions of serine residues identified as phosphoacceptors in the P protein of the CVS strain. White triangles indicate the positions of the four methionines used for internal translation initiation in the CVS strain. Asterisk indicates specific amino acid substitutions of $\mathrm{P}$ genes of only 24 Korean RABVs found in amino acid 91 (valine). The lysine-rich motif (FSKKYKF) and LC8 binding motif (RSSEDKSTQTTGR) were shown as continuous and double-continuous underlining, respectively.

\section{Discussion}

In the P gene, intragenotypic nt and aa similarities of $73.5 \%$ and $79.3 \%$, respectively, were indicated while intergenotypic similarities between RABV and other virus GTs ranged from $65.9 \%$ and $69.7 \%$ (for ABLVs) down to $56 \%$ and $45.5 \%$ (for MOKVs) [14]. Among previously reported $\mathrm{RABV}$ isolates, the $\mathrm{P}$ genes of the 
Korean RABVs showed the highest nt and aa similarities (95.5 99.0\% and 95.9 99.0\%, respectively) with V739 (dogs, Korea), NNV-RAB-H (humans, India), NeiMeng 925 (raccoon dogs, China), and RU9.RD (raccoon dogs, Russia) of GT I of lyssavirus.

In the phylogenetic tree, we found all 24 Korean RABV isolates to be categorized in the Carnivora-related RABV cluster. All 24 were closely clustered together within the same lineage regardless of species origin. The Korean RABV isolates of this study were most closely related to the V739 isolated from Korean dogs, as well as being close to NeiMeng925 (raccoon dogs, China), RU9.RD (raccoon dogs, Russia), and NNV-RAB-H (humans, India).

Based on the nt sequences of the $\mathrm{N}$ and $\mathrm{G}$ genes, the Korean RABV isolates were confirmed as GT I of lyssavirus, were clustered into four distinct subgroups (Gangwon I, II, III, and Gyeonggi) with high similarities. The isolates were most closely related to the NeiMeng1025B (raccoon dogs, Eastern China), and 857r (raccoon dogs, Russia) [24].

Similar to the $\mathrm{N}$ and $\mathrm{G}$ genes, $\mathrm{P}$ gene sequence analyses revealed that all of the Korean isolates were classified into GT I of the lyssavirus. However, unlike the $\mathrm{N}$ and $\mathrm{G}$ genes, the $\mathrm{P}$ gene was not separated into distinct subgroups because the 24 isolates were collected only from Gangwon-do Province. In the phylogenetic tree, $\mathrm{P}$ genes of Korean RABV isolates were most closely related with NeiMeng925 (raccoon dogs, China) and RU9.RD (raccoon dogs, Russia). These findings are consistent with the results found for the $\mathrm{N}$ and $\mathrm{G}$ genes. Overall, the Korean RABV isolates show genetic closeness with RABV strains from Northeastern Asia (China and Russia) and are pathogenic in several hosts including dogs, raccoon dogs, and cattle.

Previous reports have suggested that two conserved domains (CD1 and CD2) and two variable domains (VD1 and VD2) have been identified based on aa sequence multiple alignments of the RABV P gene $[14,15]$. The variable domains located on the surface structure of the $\mathrm{P}$ protein are believed to be involved in host/viral interactions and adaptation to the host environment, and are expected to be useful in elucidating the adaptive evolution of the rabies virus $[12,14,16]$. However, the VD and CD of the P genes among the 24 Korean RABV isolates examined in the current study were found to be highly conserved. Prior to the current findings, a commonly held belief was that variants of Korean RABV in the variable domains occurred at low frequencies. We found that the Korean RABV maintained a conserved sequence of the $\mathrm{P}$ gene during transmission.

In addition, specific consensus sequences of Korean RABVs lineage including V739, NeiMeng925, RU9.RD, and NNV-RAB-H in the phylogenetic tree were detected as KEPS(N/S)LGGVTTA encoded by aas 61 72 within VD1. Moreover, a specific substitution was found in aa 91 of Korean RABV P genes between VD1 and VD2. These findings suggest that the specific consensus sequences and aa substitution using $\mathrm{P}$ genes are helpful in identifying epidemiological characteristics like geographic origins of Korean RABVs lineage or Korean isolates.

Of the five serine phosphoacceptors identified for the CVS strain, Ser $_{210}$ and Ser $_{271}$ within the PKC phosphoacceptor were conserved in all lyssavirus GTs (1 7) $[12,14]$. The phosphoacceptors of $\operatorname{Ser}_{64}, \operatorname{Ser}_{162}, \operatorname{Ser}_{210}$, and $\mathrm{Ser}_{271}$ were retained in all Korean RABVs, while $\mathrm{Ser}_{63}$ was substituted with $\mathrm{Pro}_{63}$ in Korean RABVs. Variation in $\mathrm{P}$ phosphorylation patterns, especially within the N-terminal region, is predicted and might form the basis of subtle differences in viral-host interactions [14]. Further analyses of phosphorylation patterns would likely offer explanations for the function of potential variations.

Four N-terminally truncated $\mathrm{P}$ proteins could be synthesized due to four methionine residues located inframe of single $\mathrm{P}$ protein sequences in the CVS strain. In particular, approximately one-half of the RABVs examined, along with the GT 4 lyssaviruses, retained $\operatorname{Met}_{69}[4,14]$. In addition, the $\mathrm{Met}_{20}$ is retained in all lyssavirus GTs [14]. In this study, among the four methionine residues, Met ${ }_{69}$ is substituted with $\mathrm{Val}_{69}$, and Met $_{20}$ is retained in all Korean RABVs. Further studies are needed to identify the biological characteristics and potential functions of truncated $\mathrm{P}$ proteins synthesized by methionine residues.

The binding motif for cytoplasmic dynein light chain (LC8) involving viral RNP axoplasmic transport along the microtubule network was recently found in $\mathrm{P}$ proteins of the PV strain [8, 17, 18]. The consensus sequence $(\mathrm{K} / \mathrm{R}) \mathrm{XTQT}$ of the $\mathrm{P}$ gene was thought to be a conserved motif and the common binding site of LC8 [13]. Although consensus sequence was located within the VD2 region, it is still strongly conserved in all Korean RABVs examined in the current study. In addition, the lysine-rich motif (N'-FSKKYKF-C') 
identified as an important C-terminal component for $\mathrm{N}$ protein binding [9], was also conserved in aas 209 215 in all Korean RABVs. These findings suggest that the functional binding sites of the $\mathrm{P}$ gene are conserved in Korean RABV. This conservation of GTs is clearly functionally important for Korean RABV to transport viral RNP with LC8 and to bind the N protein, which are essential for RABV pathogenicity and replication.

In conclusion, this study revealed that the $P$ genes of Korean RABVs are genetically close to those of RABV strains of the lyssavirus GT I from Northeastern Asia, including V739 (dogs, Korea), NNV-RAB-H (humans, India), NeiMeng925 (raccoon dogs, China), and RU9.RD (raccoon dogs, Russia). The P genes of Korean RABVs showed low variability in the variable domains; they had specific consensus sequence and aa substitution capable of identifying geographic characteristics and retained specific sequences thought to be important for viral function in the $\mathrm{P}$ genes of RABV. This study will be helpful in understanding the genetic characteristics and viral functions of Korean RABV on the basis of the P gene.

\section{References}

1. Bourhy H, Kissi B, Tordo N. Molecular diversity of the Lyssavirus genus. Virology 1993, 194, 70-81.

2. Brzozka K, Finke S, Conzelmann KK. Identification of the rabies virus alpha/beta interferon antagonist: phosphoprotein $\mathrm{P}$ interferes with phosphorylation of interferon regulatory factor 3. J Virol 2005, 79, 76737681.

3. Brzozka K, Finke S, Conzelmann KK. Inhibition of interferon signaling by rabies virus phosphoprotein P: activation-dependent binding of STAT1 and STAT2. J Virol 2006, 80, 2675-2683.

4. Chenik M, Chebli K, Blondel D. Translation initiation at alternate in-frame AUG codons in the rabies virus phosphoprotein mRNA is mediated by a ribosomal leaky scanning mechanism. J Virol 1995, 69, 707-712.

5. Gould AR, Hyatt AD, Lunt R, Kattenbelt JA, Hengstberger S, Blacksell SD. Characterisation of a novel lyssavirus isolated from Pteropid bats in Australia. Virus Res 1998, 54, 165-187.

6. Gupta AK, Blondel D, Choudhary S, Banerjee AK. The phosphoprotein of rabies virus is phosphorylated by a unique cellular protein kinase and specific isomers of protein kinase C. J Virol 2000, 74, 91-98.

7. Hyun BH, Lee KK, Kim IJ, Lee KW, Park HJ, Lee OS, An SH, Lee JB. Molecular epidemiology of rabies virus isolates from South Korea. Virus Res 2005, 114, 113-125.

8. Jacob Y, Badrane H, Ceccaldi PE, Tordo $\mathbf{N}$. Cytoplasmic dynein LC8 interacts with lyssavirus phosphoprotein. J Virol 2000, 74, 10217-10222.

9. Jacob Y, Real E, Tordo N. Functional interaction map of lyssavirus phosphoprotein: identification of the minimal transcription domains. J Virol 2001, 75, 96139622.

10. Kim CH, Lee CG, Yoon HC, Nam HM, Park CK, Lee JC, Kang MI, Wee SH. Rabies, an emerging disease in Korea. J Vet Med B Infect Dis Vet Public Health 2006, 53, 111-115.

11. Knipe DM, Howley PM, Griffin DE, Lamb RA, Martin MA, Roizman B, Straus SE. Field Virology. 4th ed. pp. 1221-1277, Lippincott Williams \& Wilkins, Philadelphia, 2001.

12. Kobayashi Y, Okuda H, Nakamura K, Sato G, Itou T, Carvalho AA, Silva MV, Mota CS, Ito FH, Sakai T. Genetic analysis of phosphoprotein and matrix protein of rabies viruses isolated in Brazil. J Vet Med Sci 2007, 69, 1145-1154.

13. Lo KW, Naisbitt S, Fan JS, Sheng M, Zhang M. The 8-kDa dynein light chain binds to its targets via a conserved (K/R)XTQT motif. J Biol Chem 2001, 276, 14059-14066.

14. Nadin-Davis SA, Abdel-Malik M, Armstrong J, Wandeler AI. Lyssavirus $\mathrm{P}$ gene characterisation provides insights into the phylogeny of the genus and identifies structural similarities and diversity within the encoded phosphoprotein. Virology 2002, 298, 286-305.

15. Nadin-Davis SA, Huang W, Wandeler AI. Polymorphism of rabies viruses within the phosphoprotein and matrix protein genes. Arch Virol 1997, 142, 979-992.

16. Nadin-Davis SA, Sheen M, Abdel-Malik M, Elmgren L, Armstrong J, Wandeler AI. A panel of monoclonal antibodies targeting the rabies virus phosphoprotein identifies a highly variable epitope of value for sensitive strain discrimination. J Clin Microbiol 2000, 38, 1397-1403.

17. Poisson N, Real E, Gaudin Y, Vaney MC, King S, Jacob Y, Tordo N, Blondel D. Molecular basis for the interaction between rabies virus phosphoprotein $\mathrm{P}$ and 
the dynein light chain LC8: dissociation of dyneinbinding properties and transcriptional functionality of $\mathrm{P}$. J Gen Virol 2001, 82, 2691-2696.

18. Raux H, Flamand A, Blondel D. Interaction of the rabies virus $\mathrm{P}$ protein with the LC8 dynein light chain. J Virol 2000, 74, 10212-10216.

19. Smith JS, Orciari LA, Yager PA, Seidel HD, Warner CK. Epidemiologic and historical relationships among 87 rabies virus isolates as determined by limited sequence analysis. J Infect Dis 1992, 166, 296-307.

20. Talbi C, Lemey P, Suchard MA, Abdelatif E, Elharrak M, Nourlil J, Faouzi A, Echevarra JE, Vazquez Morn S, Rambaut A, Campiz N, Tatem AJ, Holmes EC, Bourhy H. Phylodynamics and humanmediated dispersal of a zoonotic virus. PLoS Pathog 2010, 6, e1001166.

21. Tamura K, Dudley J, Nei M, Kumar S. MEGA4:
Molecular Evolutionary Genetics Analysis (MEGA) software version 4.0. Mol Biol Evol 2007, 24, 15961599.

22. World Health Organization (WHO). WHO expert committee on rabies. World Health Organ Tech Rep Ser 1992, 824, 1-84.

23. Yang DK, Oh YI, Cho SD, Kang HK, Lee KW, Kim YH, Song JY. Molecular identification of the vaccine strain from the inactivated rabies vaccine. J Bacteriol Virol 2011, 41, 47-54.

24. Yang DK, Park YN, Hong GS, Kang HK, Oh YI, Cho SD, Song JY. Molecular characterization of Korean rabies virus isolates. J Vet Sci 2011, 12, 57-63.

25. Yang J, Hooper DC, Wunner WH, Koprowski H, Dietzschold B, Fu ZF. The specificity of rabies virus RNA encapsidation by nucleoprotein. Virology 1998, 242, 107-117. 